\title{
Administrative Contracts of the Public Procurements in Albania - The Distinctive Features of Their Juridical Nature and Invalidity
}

\author{
Phd.Candidate Artan SPAHIU \\ Lecturer at the Department of Law, "A.Xhuvani" University, Elbasan, Albania \\ E-mail: artan_spahiu@yahoo.com.
}

Doi:10.5901/mjss.2014.v5n2p499

\begin{abstract}
The increase of the state role in public services and investments has lead to a numerical increase of the administrative contracts in these last years, in particular to the public procurement field and as a result there is a greater need to modernize the law in this area. The actions taken by the public administration institutions, which based on the law need to contract private operators in order to exercise public functions, are considered as administrative activities. Nevertheless, while accomplishing these activities and especially when dealing with conflicts arising from these contracts, there are certain principles of the private rights which are exercised. The sensitivity towards the public contracts performance is quite high by every subject interested, in particular by the participant operators in these contracts, and undoubtedly by the taxpaying public. Based on this sensitivity, this paper analyzes the dualistic juridical natyre of the administrative contracts, especially of the ones in the public procurement area, focusing legal aspects of their validity.
\end{abstract}

Keywords: administrative contracts, public procurement, law, public administration.

\section{Introduction}

Throughout the last century, government expences have increased in most countries, regardless of their level of development, which has caused an increase in the volume and value of public procurement. With the growth of the public sector, there was also a need to seek support from the private sector in the provision of works, goods and services on a contractual basis. This fact became a reason for the reassessment of the public procurement legislation in all these countries. Even Albania, in the context of the harmonization and modernization of the legislation, possesses today a comprehensive legal framework in the field of public contracts, such as those on the public procurement ${ }^{1}$, auctions ${ }^{2}$, concessions and recently even for the public-private partnership relations ${ }^{3}$. However, the Albanian law doctrine in general and the administrative in particular, has not seriously treated the juridical characteristics of these contracts.

The above contracts are considered by the Albanian legislation as Administrative Contracts ${ }^{4}$, being treated as a form of activity of the public administration, which intends and has as its ultimate goal realizing the overall public interest. Although an administrative act is the most obvious way of exercising power and administrative functions, it is not the only way ${ }^{5}$. This activity can also be developed through private law rules. Viewed from this perspective, public administration expresses its will through another different action - the administrative contract (Sadushi, 2008, p.347). Having defined the latter as administrative acts of private law, the legal doctrine treats them as instruments of private law, which the administrative bodies use to perform a public function (Sadushi, 2008, p.347). In this sense, the administrative contract appears as a legal institution which combines the private contractual law with the public law (Légier, 2008, p.1; Sadushi, 2008, p.351), thus demonstrating legal features of the two areas of law.

\footnotetext{
1 Law No.9643, dated 20.11.2006 "On Public Procurement" (PPL), amended by law no.9800/2007, law no.9855/2007, law no.10170/2009, law no.10309/2010, law no.22/2012 and law no.131/2012.

2 Law no.9874, dated 14.2.2008 "On Public Auctions" (PAL), amended by law no.10346/2010.

3 Law no.125/2013 "On Concessions and public-private partnership relations" (PPPL)

4 See article 151/2 of the Code of Administrative Procedure of the Republic of Albania (CAP), Law no.8485, dated 12.05.1999.

${ }^{5}$ Article 2, par.2, of CAP, foresees that: "The forms of the administrative activity regulated by this law are: a) collective and individual administrative acts; b) administrative contracts; and c) real acts".
} 


\section{Characteristics of the Juridical Nature of Administrative Contracts in the Albanian Legislation}

Let us stop and analyze the characteristics manifested by the juridical nature of these contracts, according to the Albanian legal framework, referring to public procurement contracts. Currently, in the Albanian legislation, there is no domestic law to regulate specifically the administrative contracts. These are new legal concepts addressed in our theory of administrative law (Sadushi, 2008, p.352).

2.1 One of the parties in the administrative contracts is always a public administration body, exercising its legal functions.

Such a conclusion, for administrative contracts, results based on the content of Article 6 of the Code of Administrative Procedure of the Republic of Albania (CAP), which only defines these contracts as an agreement, where at least one of the parties is a body of public administration and which creates, amends or extinguishes a legal relation of public law. Besides the definition, CAP provides a list of these contracts ${ }^{6}$, which is not exhaustive, as administrative contracts are not only those cited in the law. The interests of the Albanian public economy can also lead in the application of other types of state-private contracting. Such an authority, to conclude contracts which are not expressly provided by law, is attributed to the public administration body, based on the principle of discretion?

According to the Albanian Public Procurement Law $(\mathrm{PPL})^{8}$, public contracts are contracts for pecuniary interest, concluded by an exchange of written communication between one or more economic operators ${ }^{9}$ and one or more contracting authorities ${ }^{10}$, which have as their object the execution of works, the supply of goods or the provision of services. Thus, according to PPL, public procurement contracts have as main features: (a) the status of the parties, where one is necessarily a public administration institution or public entity ${ }^{11}$; (b) compensation or remuneration; (c) form, which is always written and (d) the object of the contract, which is the provision of works, goods and services for the public interest. The same features can be found in the legal nature of the public auctions contracts, except that the object of the auction contract includes only objects (goods) and the role of seller goes to the public administration body, while the economic operator always takes the role of the buyer ${ }^{12}$.

\subsection{Administrative contracts essentially protect the public interest.}

As stated above, administrative contracts are administrative actions ${ }^{13}$, whose fundamental mission is concerned with the

\footnotetext{
${ }^{6}$ The article 151, par.2 of CAP, lists as administrative contracts: a) public work undertakings; b) public work procurement; c) public services procurement; ç) games of chance licensing; d) continuing supplies contracts; dh) contracting for services provided by private subjects in cases of natural disaster.

${ }^{7}$ CAP, Article 7 "Discretionary Power (discretion)": Discretionary power of public administration shall mean the right of the latter to exercise the public authority for accomplishment of a legal objective, even without an expressed authorization of the law.

8 PPL, article 3.

9 Id., article 3, par.13: "Economic operators" are all the "contractors", "suppliers" and "service providers", without distinction between them, which means any natural or legal person or public entity or group of such persons and/or bodies which offers on the market, respectively, the execution of works or the supply of goods or services.

10 ld., article.3, par.14: "Contracting authorities" mean all those entities subject to the PPL for the execution of their public contracts. Namely, the following: a) constitutional and other central institutions, independent central institutions, local governing entities; b) any bodies: (i) established for the specific purpose of meeting needs in the general interest, not having an industrial or commercial character; (ii) having legal personality; and (iii) financed, for the most part, by the State, regional or local authorities, or other public bodies; or subject to management supervision by those bodies; or having an administrative, managerial or supervisory board, more than half of whose members are appointed by the State, regional or local authorities, or by other public bodies; c) associations formed by one or several of such authorities or one or several of such public bodies; ç) any other public body.

${ }_{11}$ Definition of Public Entity is expressed in article 1 of law No.8480, dated 27.05.1999 "On the functioning of collegial organs of state administration and public entity", which foresses that: "Public entity implies every non-state subject of public law, established by the law which aim the execution of the public interest".

12 PAL, article 3, par.6: "Contrats of public sale" are contracts signed between one or more buyers and selling authority, whose aim is to sell every public object which has an economic value, in accordance with this law".

${ }_{13}$ See Article 2(7) of law no.49/2012 "On the organization and functioning of the administrative courts and the judgement of administrative disputes", which foresees that: "administrative action" means an administrative act, the administrative contract and other administrative action".
} 
public interest ${ }^{14}$. Administrative contracts, being contracts concluded mainly in order to serve public interest aims, are given a special status by the legislator, which accordingly differentiates them from private law contracts (Kaltsa \& Kourtesi, 2000, p.322). The legal framework that governs these contracts is established upon principles that guarantee the public interest, such as: promoting competition, equal treatment, transparency, efficient use of public funds, public trust, and etc ${ }^{15}$

The administrative authority is not equal to the other contracting party because of the interest that it represents and defends in these legal relationships. This means that in all administrative contracts, provided or not by the CAP, the administrative bodies are placed in a more favorable position than the other private party. Therefore, in these cases, they have the privilege to overcome, or, in some specific circumstances, to set aside the contract, but without denying the right of the other party to be rewarded for the damage caused. The right of public authority to intervene at any moment, and even to withdraw unilaterally, in the cases provided by the law, when the public interest is affected, is a feature of these contracts (Sadushi, 2008, p.348).

The public administration is given a right to unilateral recess only in the presence of important justification of public interest. The delicate question of interpretation lies in the definition of the degree of the public interest importance in absolute terms and in relation to the opposing private interests, which are often of considerable economic and entrepreneurship importance (Claudio, 2008, p.10). For some authors, not every public need enables the withdrawal from administrative contracts, by accepting as a public interest only the urgent public needs that cannot be met without "sacrificing" the interests of the private party in the contract (Bruti Liberati, 1996, p.194.) However, even these cases of public interest must be addressed within the limits of proportionality, which is a very important principle of the administrative activity ${ }^{16}$.

The Albanian legislation on public procurement provides that the public interest prevails and it may lead to the termination of public procurement procedures, whenever cases of violation of this interest are identified ${ }^{17}$. Likewise, the legal framework governing public-private partnership explicitly foresees the unilateral termination of the contract by the agency or public entity, when the concessionaire fails to fulfill some contractual obligations that affect the public interes ${ }^{18}$. In some cases, the legal framework provides that infringement of the public interest, in the form of violation of transparency of the procurement procedure, or disrespecting the administrative appeal procedure, can lead to the absolute nullity of the administrative contract ${ }^{19}$. Meanwhile, the Albanian judicial practice has a similar stance, stating that: "Withdrawal of the administrative authority from the administrative contract happens only if it violates its lawful cause $^{20}$. The power of the administrative authority to break administrative contracts is recognized when it is exercised in

${ }_{14} \mathrm{CAP}$, article 151, par.1: "The administrative contract is an agreement by means of which a legal relation of public law is created, modified or terminated".

${ }_{15}$ PPL, article 1, par.2: "The objectives of the law are: (a) to promote efficiency and efficacy in public procurement procedures carried on by contracting authorities; (b) to ensure a better use of public funds and reduce procedural costs; (c) to encourage economic operators to participate in public procurement procedures; (c) to promote competition among economic operators; (d) to guarantee an equal and non-discriminatory treatment for all economic operators participating in public procurement procedures; (dh) to guarantee integrity, public trust and transparency in public procurement procedures".

16 The principle of proportionality, which is part of the principles of reliability and predictability, fundamentally understands that administrative action should be proportionate to the aim to be achieved in accordance with the law. The principle of proportionality, which is associated with the "reasonableness" (a reasonable deadline, a reasonable way), is especially developed by the European Court of Justice.

${ }_{17}$ PPL, article 24, par.1,2: "Contracting authorities are allowed to discontinue the awarding procedure, for public interest, provided that the principles of equality and transparency are complied with. Contracting authorities are not obliged to award a contract in any case. Contracting authorities shall incur no liability towards tenderers who have submitted tenders solely by virtue of their invoking paragraph 1 of this Article".

18 Law Nr.125/2013 "On concessions and public-private partnerships", in article 36(1) provides that a contracting authority may terminate the contract if: a) it can prove that the private partner can not perform its obligations due to payment disability, serious violations or other issues that prevent or do not allow the continuation of the contract ....b) the concessionaire / private partner fails to ensure the financing of the project within 12 months from the signing or the entry into force of the contract ...

19 ld., article 26: "Where the contract is signed before the end of the deadline for the classification notice or before termination of the administrative review, the contract is considered null and void"; see also the identical provision of article 58(6) of the PPL: "Where the contract is signed before the end of the deadline for the classification notice or before termination of the administrative review, the contract is considered null and void".

${ }^{20}$ Civil Code of Albania, article 663 "Requisites of Contracts": "The requisites of the contract validity are: the agreement of the party that has undertaken the obligation, the lawful cause for the obligation, the object that forms the content of the contract, and the form as prescribed by law". 
favor of the public interest and when this action is explicitly recognized in the law"21.

\subsection{Alienation from the concept of contractual freedom of the parties}

In administrative contracts, the principle of freedom of the will of the parties is narrowly understood when compared with the dimension that this principle takes in private contracts, although, even for the latter, it is widely discussed today about the relativity of the concept of freedom of the parties ${ }^{22}$. As a party in the administrative contracts, the public administration has not been authorised a negotiating autonomy and a contractual freedom as in the case of civil contracts (Sadushi, 2008, p.348.). Thus, firstly, in the area of procurement, the freedom of the public authority to enter into contractual relations, a concept that includes even the freedom of not concluding a contract, is limited. This is because the public administration body is obliged, by law, to provide public service, which has a financial cost borne by public funds. In these circumstances, the public body or entity is imposed the status of the contracting authority, being forced to contract a work, good or service ${ }^{23}$. Secondly, the selection of the private contracting party, in an administrative contract, belongs indeed to the administrative body, but based on a procedure welldefined by law. Consequently, the public body or entity is not free to contract with any operator the he "likes", but only with those, who accomplish some conditions, according to the law, and which are selected by some strict legal procedures ${ }^{24}$. Moreover, although the administration has a discretional power in selecting private contractors, such a procedure is controllable by the highest body in the administrative control line, which has the right to dispose up to the cancellation of a procurement procedure ${ }^{25}$. Thirdly, the terms and conditions of the contract concluded at the end of a procurement procedure are not determined by the free will of the parties, as they are, in the vast majority of cases, predefined under certain standard conditions, which are approved by the legal framework for these types of contracts and can not be changed ${ }^{26}$.

\section{Administrative Contracts and Private Law Principles in the Albanian Legislation}

Despite the existence of specific statutory provisions, the domestic legislation, when it comes to the implementation of administrative contracts, refers to a considerable extent the principles and rules of private law, as provided by the Civil Code of the Republic of Albania27. Furthermore, in the case of public procurement contracts, certain provisions of this

${ }^{21}$ See Decision of the Supreme Court no.431, dated 11.10.2012 (No.31003-01685-00-2011 Reg.Charter; No.00-2012-2422 of the Decision), on the case "Society "Marketing \& Distribution" Ltd. versus the Municipality of Elbasan"

22 See Guido Alpa (2010), Party autonomy and freedom of contract today, cited: "The debate on the fate of freedom of contract and thus of the contract in modern times reflects the complexity of the economic and social situation which has come to be outlined in the last few years and the complexity of sources. The concept of contractual freedom has been discussed as an expression of an authentic liberal vision of the action of the parties and the responsibility of the legislature (community or national) in pursuing social interests which could be neglected or worse denied by agreement between the parties".

${ }^{23}$ Council of Ministers Decision (CMD) No.1, dated 10.01.2007 "On public procurement rules", as amended, Chapter V, section 1(c): "With the approval of the budget law and the need for works, goods and services, the head of the contracting authority or the authorized officer shall immediately issue a procurement order ....".

${ }^{24}$ Id., Chapter I, Section 1, provides that: "The Contracting Authority is responsible for the procurement with the public funds, in accordance with the provisions of the Public Procurement Law, the Decision No.1 and the Guidelines of the Public Procurement Agency (PPA)". The latters have set strict rules, with respect to estimating the limit value of a public contract, the monetary limits of the procedures, the standard documents of the tender, the winner selection procedures, deadlines and rules of notices, etc.

${ }^{25}$ PPL, article 19/1: "Public Procurement Commission (PPC) is the highest in the area of procurement, which investigates complaints about procurement procedures, in accordance with the requirements specified in this law. In the conclusion of the review of complaints, make decisions, which are administratively final". Article 24, paragraph 1(f): "The contracting authority cancels the procurement procedure when the Public Procurement Commission decides cancellation".

${ }^{26}$ PPL, article 60, par.1: "The terms of the contract awarded pursuant to the PPL shall not differ from the prescriptions established in the tender documents and in the successful tender (winning bid)"; see also CMD No.1, dated 10.01.2007, Chapter III, paragraph 1(a): "PPA prepares the format of the standard tender documents, which provide information on the scope of the contract and the type of procedure, ... During the preparation of tender documents, the contracting authority shall use standard documents as defined in the rules of procurement ...".

${ }^{27}$ PPL, article 60, par.3: "Without prejudice of the provisions of the PPL and any other legislative provisions applicable to contracting authorities, contracts awarded pursuant to the PPL shall be subject to Albanian Civil Code"; See also Law nr.125/2013 "On concessions and public-private partnerships", article 27(2): "Contract issues, which are not regulated by this law are subject to the provisions of the Civil Code". 
Code are re-expressed in the General Conditions of Contract ${ }^{28}$, in order to increase the transparency of these conditions, while not denying the application of other provisions of the Civil Code. This Code defines the general principles of private law transactions, which is inter alia the good faith principle, aplied in the negotiation phase ${ }^{29}$, during execution of the contract $^{30}$ and also in interpreting the contract ${ }^{31}$. The law thus subjects these relationships to the general principles of good faith, since it's social and economic consequences go beyond the inter partes relationship (Kaltsa \& Kourtesi, 2000, p.322).

The spirit in favor of good faith compliance of the administrative contract terms, by the contracting parties, is found even in the special procurement legislation ${ }^{32}$. Not only the legal framework but also the Albanian jurisprudence is in favor of the intervention of private law principles in the performance of administrative contracts. It is important to mention here the Supreme Court's decision no.431 dated 11.10.2012, on the "Marketing \& Distribution "Ltd. Association v. Municipality of Elbasan", where the court stated that the terms of the contract are subject to the relevant provisions of the Civil Code and in the absence of public interest, recognized in the law, all disputes shall be subject to judicial review, as all other contracts of private law ${ }^{33}$. As a conclusion, the domestic legal framework and the judicial practice demonstrate that the courts implement private law provisions in administrative contracts when the other protective provisions of the lex specialis are unable to give a sufficient remedy.

\section{Terms of Invalidity of the Administrative Contracts}

From the above considerations, we conclude that the same rules that operate to invalidate the administrative acts shall be applied even for the validity of administrative contracts. What is more, for this purpose, the rules that operate in determining the validity or invalidity of contracts in private law will also be applied.

\subsection{Administrative invalidity of public contracts.}

According to the administrative law, the invalidity is an unlawful juridical situation, created by the public administration body through the wrong application of the law or of the juridical will, which is displayed affecting administrative concrete action. The full and correct definition of the administrative act invalidity is provided by the Code of Administrative Procedure (CAP). The latter has no special adjustment for the validity of administrative contracts, but the logic of the Code itself and its Commentary ${ }^{34}$ explains that the same rules that operate to invalidate the administrative act apply even for the administrative contracts. The CAP defines that acts (including administrative contracts) issued in violation of the law are invalid. The level of opposition or violation of law is the only factor that determines the degree of invalidity of the administrative acts. So, if it is a flagrant violation of the law, the invalidity is absolute, while if we are dealing with a simple (ie non-flagrant) violation of the law, invalidity is relative. ${ }^{35}$

${ }^{28}$ Standard Tender Document, approved by PPA with the Instruction dated 01.02.2013 (www.app.gov.al), General Conditions of Contract, Article 1(2).

${ }^{29}$ Civil Code, article 674, par.1: "During the negotiation and formation of the contract the parties must act in good faith with one another"

30 Id., article 455: "The debtor and the creditor must show the proper care and must be punctual in the accomplishment of the obligation according to its content".

${ }^{31}$ Id., article 682: "The contract shall be interpreted according to good faith".

${ }^{32}$ PPL, article 60(2): "All terms of the contract awarded pursuant to the PPL shall be performed in good faith by both parties".

${ }^{33}$ The decision of the Supreme Court no.431, dated 11.10.2012: "The College estimates that, between litigants are connected administrative contracts. With the conclusion of contracts, as defining its general conditions, responsibilities of the parties, opportunities to withdraw from it, etc., as contractual freedom of the parties are subject to the relevant provisions of the Civil Code. So, these administrative contracts are a combination between general rules of the Code of Administrative Procedures and those of the Civil Code. The legal cause on which the obligation between the parties is based on the administrative contract constitutes, as well as in private law contract, one of the main conditions for their relevance and validity. Waiver of administrative authority by administrative contract is done only if it violates its legal cause. The power of the administrative authority to cancel administrative contracts is recognized when it is done for the interest of the public and when it is explicitly recognized in law. Otherwise, all other disputes are subject to judicial review, as all other contracts of private law".

${ }^{34}$ See Ibrahimi G., Sadushi S., Lako A., Caka B. "Comentary of the Code of Administrative Procedure", "Flesh" ed., Tirana 2001.

${ }^{35} \mathrm{CAP}$, article 115: "Invalidity of administrative acts....is presented in the following cases: a) administrative acts absolutely invalid (acts issued in flagrant violation of the law); b) administrative acts relatively invalid (acts issued in violation of the law)". 


\subsubsection{The absolute invalidity in the procurement contracts.}

Referring to Article 116 of the CAP, which exhaustively lists the cases of absolute nullity, we can conclude that null and void are to be considered those administrative procurement contracts, which are concluded:

i) from an unidentified administrative body36: when the procurement contract is concluded by an administrative body, which has not been created by law or a legal act, or that has not been created for procurement purposes;

ii) an administrative body, beyond its legal competencies ${ }^{37}$ : when the public entity, established by law, has implemented a procurement process, while it was not within its competence; or

iii) contrary to the form and procedure, required by law ${ }^{38}$ : when the contract was concluded without respecting the requirements of the procedural steps to be followed, provided by the special legal framework for procurement and the conflict of interest law ${ }^{39}$, but also the requirements of the CAP for the form an administrative contract should have 40 .

As stated above, an administrative procurement will be valid only if it is concluded after having followed a public procurement procedure, which (a) is conducted by an administrative body established by law, (b) exercising its clear legal competencies and which (c) respect the form required by law and all procedural steps.

\subsubsection{The relative invalidity of the procurement contracts.}

The Code of Administrative Procedure ${ }^{41}$ defines that the relative invalidity cases are violations of the law, but not flagrant ones. In reference to this provision, we can conclude that relatively invalid are to be considered those administrative procurement contracts, which are concluded:

i) inconsistently with the content or purpose of the law: when creating favors, facilities or rights, at a time when the law does not allow them (eg. an economic operator which is qualified in a procurement procedure, though it does not meet the criteria for participation as defined by law); or when stopping or refusing the rights, which are allowed by law (eg. an economic operator excluded from the procurement process, though it meets all the criteria set by the law);

ii) based on an illegal act (such as a procurement procedure conducted under an instruction of the Public Procurement Agency which is enacted against the law);

iii) under the influence of the incorrect will of the parties (eg. when a party has concluded a procurement contracts beeing defrauded, threatened, or when he has made an essential error related to the object of the contract, or when he has acted because of an extreme necessity ${ }^{42}$ ).

\subsection{Administrative contracts in a conflict of interest.}

The Albanian legislation, which regulates issues of conflict of interest, clearly states that administrative contracts concluded in conditions of conflict of interest are invalid, referring to the qualification of invalidity according to the CAP principles ${ }^{43}$. The same legislation also makes a distinction between several cases of conflict of interest which, according

\footnotetext{
${ }^{36} \mathrm{CAP}$, article 116 , par.(a)

37 Id., par.(b)

38 Id., par.(c)
}

39 Law no.9367, dated 07.04.2005 "On the prevention of conflicts of interest in the exercise of public functions".

40 It is discussed at length in the literature of administrative law on this last point of the absolute nullity, by determining that it is not necessarily needed that both the form and the procedure are infringed, in order to lead to absolute invalidity. Violation of only one of them suffices. However, the doctrine and practice has held that, in some cases, if it's a procedural violation or form violation not expressly required under the special law (lex specialis), invalidity may even be relative. So the position is related to the degree of the law violation. It is the duty of the judicial or administrative body that examines the issue of invalidity, to analyze the type of invalidity, based on these basic pillars.

${ }^{41}$ CAP, article 118, par.1: "The administrative acts will be called relatively invalid, on the understating of this Code, when they have been issued in violation of the law, but nevertheless are not absolutely invalid".

${ }^{42}$ See article 94, 95, 96, 97, 98, 99 of the Albanian Civil Code.

43 Law no.9367, dated 7.4.2005 "On the prevention of conflicts of interest in the exercise of public functions", article 40(1): "Administrative contracts and acts of every public institution, and appealing against them, issued under the conditions of an actual or 
to the lex specialis, make the administrative contract absolutely invalid ${ }^{44}$ and other cases, which lead to relative invalidity 45 . Thus, an administrative procurement contract, concluded between a public entity and a natural person who is an official of a certain level in this institution, is absolutely invalid. In this case, the legislator has deemed flagrant violation of the law by providing an absolute invalidity for the contract.

As discussed above, it can be supported the conclusion that administrative contracts, concluded during the process of public procurement, under conditions of conflict of interest, can be absolutely or relatively invalid, depending on the concrete situation in which the contract was concluded and the level of the violation of law (flagrant or not).

\subsection{The civil invalidity of administrative contracts.}

As noted above, so as to judge the validity of administrative contracts we must address the principles and rules of the civil law. Under these rules, the invalidity of the contract and its degree (absolute or relative), as well as the dispute resolution arising from this invalidity, shall be determined by the court and not by an administrative body. In these cases, the court must refer to the civil law, not only because it is a contract, but also because of the fact that our legislation of administrative law is not sufficient to resolve the conflict in a bilateral agreement.

The civil terms of invalidity in the administrative contracts are those provided in the Civil Code (Articles 92-102) on the invalidity of a legal action, including the reasons that make a legal action (an administrative contract) absolutely ${ }^{46}$ or relatively ${ }^{47}$ invalid. Moreover, other conditions of the invalidity of administrative contracts are expressly cited in special laws: firstly, the conclusion of an administrative contract in case of a conflict of interest (absolute or relative nullity) ${ }^{48}$ and secondly, concluding the procurement contract before the end of the deadline for the classification notice or before termination of the administrative review (absolute nullity) ${ }^{49}$.

The question being raised for the procurement contracts is: if the conditions of invalidity referred above exist, is the competent administrative authority given the possibility to order the termination of the contract unilaterally? In fact, public procurement law provides for such a possibility only when the contract is concluded before the expiry of the classification notice, or before the completion of the administrative review. For all other cases, the law has explicitly removed the right from the administrative bodies which control the procurement process ${ }^{50}$ and what is more even from the administrative contracting authority itself, to nullify the contract due to invalidity, if the contract is signed, even if it indeed is concluded under invalid conditions ${ }^{51}$. This means that, despite the existence of illegality in procurement procedures, the procurement contract continues to create legal effects and it belongs to the court only to review the invalidity of the administrative contract and to resolve the juridical consequences that come from it ${ }^{52}$. In addition, the analysis of the legal consequences, created from an administrative contract, concluded in the presence of a conflict of interest situation, will be an issue that in no case shall belong to the administrative bodies, but to the court only. The judicial practice shows

apparent conflict of interests, are invalid, according to the meaning of this term and the principles and procedures defined in the Code of Administrative Procedures".

${ }_{44}$ Id., article 40(2): "Every civil contract, entered in conflicting with the paragraphs 1, 2 and 3 to the article 21 of this law, or in any other case when it is completed in the presence of an actual or apparent conflict of interest, does not create any legal consequence".

45 Id., article 40(4): "The acts specified in the letter "a"/"iii" of the paragraph 1 to the article 4 of this law, issued in the presence of an actual conflict of interest, are relatively invalid, according to the same terms used for administrative acts in CAP".

${ }^{46}$ Civil Code of Albania, article 92: "The invalid legal transaction do not create any legal consequence. Such ones are those which:a) come clearly against an ordering provision of law; b) are performed to defraud the law; c) are performed by infants under age of fourteen; d) are done in agreement between parties without aiming to bring legal consequences (fictive or simulating)".

47 Id., article 94: "Legal transactions declared as invalid (annulled)" - "Annuled are considered the legal transactions which are valid until the court, by the request of the interested, declares them invalid. Such ones are legal transactions performed by: a) Infants over age of fourteen, when the juridical transaction is performed without the assent of parent or tutor. b) Persons who because of mental diseases or defects have no capacity to act or it is taken off, when the legal transaction is performed by them without the assent of the protector. c) Persons who at the moment of performance of the legal transaction were not conscient of importance of their acts, besides the fact that at that time there was not taken off the capacity to act. d) Person who has committed a legal transaction beeing defrauded, threatened, who has mistaken or because of great necessity".

48 The Law on Conflict of Interest, article 40, par.(1), (2).

49 PPL, article 58, par.(6).

50 Public Procurement Commission (PPC), Procurement Advocate (PA), or Public Procurement Agency (PPA).

${ }_{51}$ PPL, article 64(4): "Following the conclusion of the public procurement contract, if the Public Procurement Commission states that a decision or action taken by the contracting authority was in breach of any of the obligations of this Law, it has the power to issue a declaratory decision based on which the complainant who suffered loss or damage, may claim damages before the Court".

52 See the Court's decision of the Juridicial District Court of Tirana, no.3127, dated 07.04.2008. 
that the court has recognized that the parties may seek compensation for the damage caused if the administrative contract is deemed invalid, based on the non-contractual liability of the administrative bodies ${ }^{53}$.

\section{Findings and Conclusions}

The juridical nature of the administrative contracts appears dualistic, manifesting legal features from two fields of law, the public and the private ones. The essence of these contracts is the fulfillment of the public interest, which attributes to the public administration the right to withdraw from the contractual obligations, in those cases when public interest is sufficiently endangered. However, the principles of public law and private law force the administrative bodies, that even in such cases to consider private interests in the administrative contracts, by applying the principle of proportionality and trust.

An administrative procurement contract will be valid only if it simultaneously meets the legal criteria of validity of an administrative act and the legal civil conditions for the validity of a private contract. Consequently, the procurement contract shall be considered valid if it is signed by the administrative body established by law, in the exercise of its legal powers, respecting all the material and procedural criteria, in free will of the parties. Moreover, the administrative contract, in order to ensure public confidence, should avoid all the circumstances of conflict of interest and strictly observe the deadlines of announcements and administrative review of claims from interested parties.

The spirit of the legal framework, but also the attitude of the judiciary, supports the narrow interpretation of the opportunity that administration may have to unilaterally invalidate the administrative contract. Accordingly, the cases when the administrative body, either party to the contract or supervisor of the process, is allowed to consider the contract as null and void due to its invalidity are exhaustively defined in the domestic law. In all other cases, despite the potential illegality in the procurement procedures, the procurement contract continues to create legal consequences and it belongs to the court only, to review the validity of the administrative contract and resolve all the consequences deriving from it.

\section{References}

Sadushi Sokol, "The administrative Law 2", 4th edition, "Grand Prind", 2008.

Ibrahimi G., Sadushi S., Lako A., Caka B. "Comentary of the Code of Administrative Procedure", "Flesh" ed., 2001.

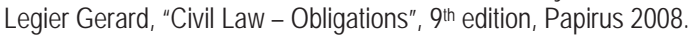

Anastasia Kaltsa \& Thomi Kourtesi, "The Implementation of Private Law Principles in Administrative Contracts", European Public Law, Volume 6, Issue 3, Kluwer Law International, 2000.

Vivani Claudio, "I contratti di servizio fra diritto pubblico e privato", Leggi d'Italia, Wolters Kluwer Italia 2008, p.10.

E. Bruti Liberati, "Consenso e funzione nei contratti di diritto pubblico", 1996.

Guido Alpa, "Party autonomy and freedom of contract today", 2010, EBLR.

Code of Administrative Procedure of the Republic of Albania (CAP), Law no.8485, dated 12.05.1999.

Civil Code of Albania, Law no.7850, dated 29.07.1994, as amended.

Law No.9643, dated 20.11.2006 "On Public Procurement" (PPL), as amended.

Law no.9874, dated 14.2.2008 "On Public Auctions" (PAL), as amended.

Law no.125/2013 "On Concessions and public-private partnership relations" (PPPL)

Law No.8480, dated 27.05.1999 "On the functioning of collegial organs of state administration and public entity".

Law no.49/2012 "On the organization and functioning of the administrative courts and the judgement of administrative disputes".

Law no.9367, dated 07.04.2005 "On the prevention of conflicts of interest in the exercise of public functions".

Council of Ministers Decision (CMD) No.1, dated 10.01.2007 "On public procurement rules", as amended.

Standard Tender Document, approved by PPA with the Instruction dated 01.02.2013 (www.app.gov.al).

Court's decision of the Supreme Court, no.431, dated 11.10.2012.

Court's decision of the Supreme Court, no.822, dated 12.05.2005.

Court's decision of the Juridicial District Court of Tirana, no.3127, dated 07.04.2008.

${ }^{53}$ See the Court's decision of the Supreme Court, no.822, dated 12.05.2005. 